\title{
INVESTIGATING VADOSE ZONE HYDROLOGY IN A KARST TERRAIN THROUGH HYDROGRAPH AND CHEMICAL TIME SERIES OF CAVE DRIPS AT GRAND CAVERNS, VIRGINIA
}

\author{
Joshua R. Benton \\ U.S. Geological Survey, 12201 Sunrise Valley Drive, MS 926A, Reston, VA, 20192, United States, \\ jbenton@usgs.org \\ Daniel H. Doctor \\ U.S. Geological Survey, 12201 Sunrise Valley Drive, MS 926A, Reston, VA, 20192, United States, \\ dhdoctor@usgs.org
}

\begin{abstract}
Caves provide useful access points for sampling and monitoring of vadose groundwater to better understand the hydrologic conditions controlling the timing and magnitude of critical recharge events. In this study, two cave ceiling drips within a single room at Grand Caverns, Virginia have been monitored simultaneously for changes in drip rate, electrical conductivity, and geochemistry from February 2014 to July 2017.
\end{abstract}

The results show distinctly different behavior in the discharge between the two drip sites. One site exhibits seasonal changes in flow rate while the other site has remained nearly constant at $0.018 \mathrm{~L} / \mathrm{h}$. The dynamic site has a lower flow regime during the summer, fall, and winter $(0.004 \mathrm{~L} / \mathrm{h}-0.008 \mathrm{~L} / \mathrm{h})$ until precipitation or snow melt events in the early spring triggered a sudden increase in discharge up to $0.328 \mathrm{~L} / \mathrm{h}$. There is an apparent volumetric soil moisture threshold of approximately $30 \%$ that must be exceeded before there is a response in the drip rate within the cave. Both the peak discharge rate and duration of the annual recharge period depends upon what time of year it occurs, with larger recharge events beginning in February and March and smaller recharge events occurring as late as April and May. This higher flow regime continues until the summer when an increase in evapotranspiration on the surface creates a soil moisture deficit that corresponds to a drop in discharge within the cave. This moisture deficit is usually not fully recharged again until winter and early spring when surface precipitation continues and evapotranspiration is low.

Stable oxygen and hydrogen isotopes of the drip water and of precipitation above the cave were measured as potential tracers for determining the seasonality of recharge to the cave drips. Despite there being large seasonal shifts in the isotopic composition of rain waters collected above the cave, the oxygen isotope composition for both drip sites have remained nearly equal and constant at $-8.0 \pm 0.1 \%$. This value is similar to the cool-season amount-weighted average of precipitation collected at the surface, and thus supports the hypothesis of a cool-season recharge bias to the drips.

\section{Introduction}

Monitoring groundwater within the vadose zone enhances the understanding of how aquifer recharge changes throughout each hydrologic season. Understanding rates of recharge into an aquifer is important for resource management and regional water budget calculations (Mathias et al., 2017). The flow rate of vadose waters in karst terrains can change quickly resulting in a sudden flux of water into the aquifer system. Cave drip water studies provide insights into processes controlling the characteristics of groundwater flow in karst terrains (Doctor et al., 2015). Many of the temporal changes in the discharge and chemistry of drip waters are the result of biological, chemical, and physical processes occurring above the cave within the soil zone and the soil-tobedrock transition zone called the epikarst. The carbonate bedrock within the epikarst is highly weathered being subject to chemical dissolution from undersaturated, meteoric waters that are not only enriched in $\mathrm{CO}_{2}$ from the atmosphere, but also from microbial respiration in the soil zone (Williams, 2008).

As a result, there is an abundance of secondary and tertiary porosity and a decrease in hydraulic conductivity at the transition from highly weathered bedrock to less weathered bedrock allowing for the temporary storage and mixing of waters within the epikarst (Eagle et al., 
2016). These features make the epikarst an important control on the physical and chemical characteristics of downward-penetrating vadose waters that ultimately take part in recharge to the regional karst aquifer (Schreiber et al., 2015). Below the epikarst the water either diffuses slowly through primary porosity and small fractures within the bedrock or transmits at a faster rate through enlarged conduits and caves (Lachniet, 2009). The purpose of this study is to use the chemical and physical changes of drip waters in a cave to learn more about the dynamics involving water transmission from the epikarst to the aquifer below. Specifically, this project tested the hypothesis of highly seasonal recharge to cave drips in the Great Valley of Virginia (Eagle et al., 2016).

\section{Location, Geology, and Climate}

Grand Caverns is a tour cave located in the central Appalachians on the eastern side of the Great Valley in the town of Grottoes, Virginia (Figure 1). Grand Caverns is within a prominent ridge called Cave Hill that contains several other large caves. The Great Valley is part of the Valley \& Ridge physiographic province which primarily consists of folded and faulted Paleozoic sedimentary rocks with minor, late igneous intrusions. Grand Caverns is completely within the Cambrian Conococheague Limestone, a shallowmarine carbonate that consists of interbedded limestone and dolostone, and minor beds of quartz sandstone (Gathright et al., 1978).

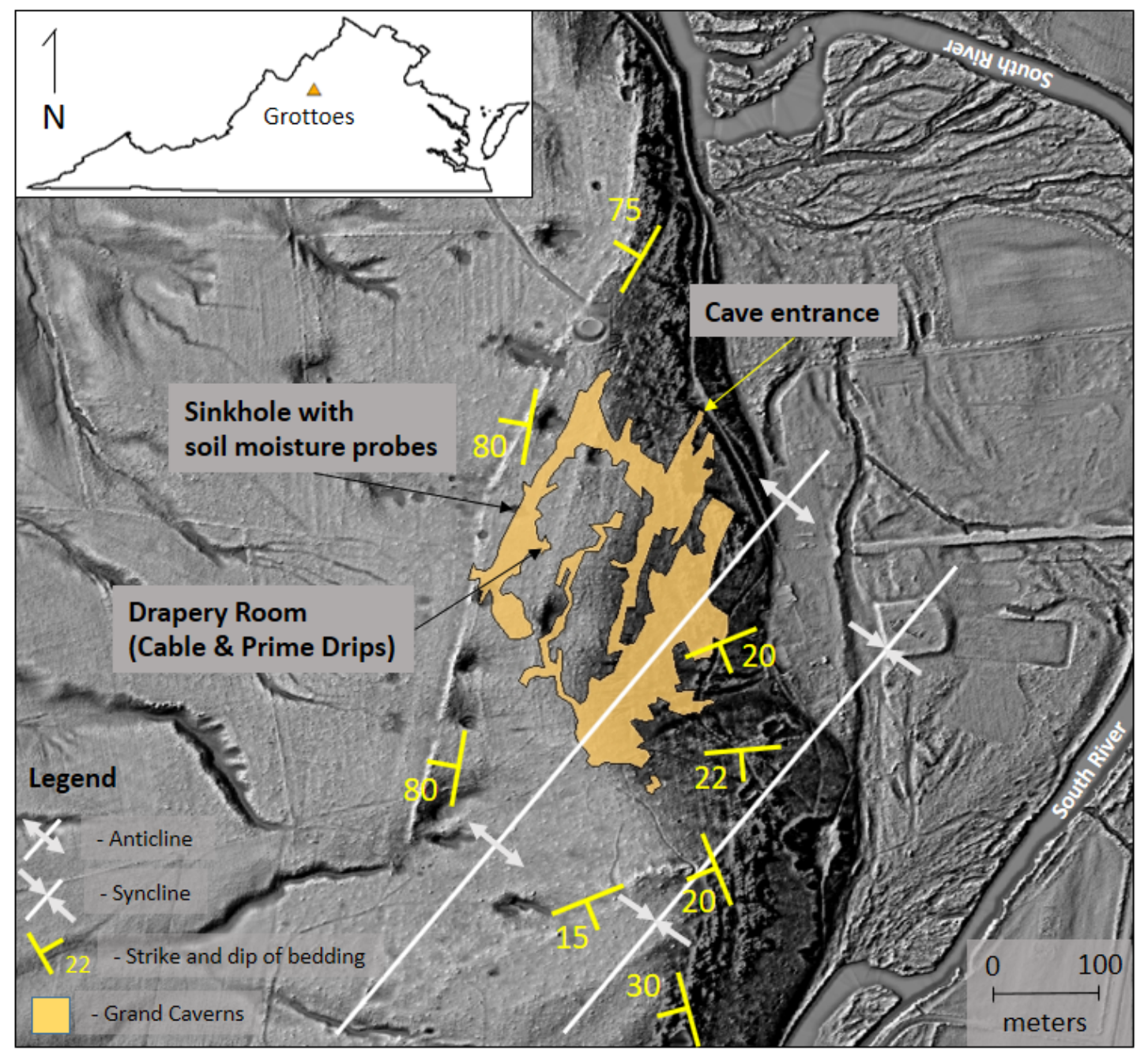

Figure 1. A map of Grand Caverns overlying a hill-shaded LiDAR-derived elevation image of Cave Hill. Bedrock structure data is also shown highlighting the axis of an anticline that extends through the eastern portion of Grand Caverns. Both of the sampling locations within the cave (Cable \& Prime Drips) are located within the Drapery Room, and the sinkhole where the soil moisture probes are installed is visible within the LiDAR image. 
The carbonate rocks in the Valley \& Ridge have a low primary porosity due to diagenetic alteration of the bedrock, and secondary and tertiary porosity created by fractures and conduits play a more important role in groundwater flow and storage. The long axis of Grand Caverns is parallel to the strike of bedding (Figure 1), which also correlates to a regional NE/SW strike of many geologic structures in the mid-Atlantic portion of the Appalachian fold belt. Structurally, this section of the Great Valley is part of the Massanutten Synclinorium, and the cavern is on the eastern limb of this broad syncline.

Cave Hill has a steeper, east facing slope that is flanked by the South River flood plain (Figure 1). It has been questioned as to whether the formation of Grand Caverns relates to the incision of the South River and the corresponding drop in the water table; however, the lack of alluvial deposits and the absence of flowing water within the cave implies Grand Caverns is a hypogenic, phreatic cave system that formed much deeper below the water table (Doctor et al., 2014).

Grand Caverns is located within a temperate climate zone at an elevation of approximately 340 meters above sea level. The outside temperature range throughout the course of the study period (2014-2017) was a high of $36^{\circ} \mathrm{C}$ in July, 2017 and a low of $-22^{\circ} \mathrm{C}$ in February 2015, and Grottoes received an average of $882 \mathrm{~mm} /$ year of precipitation (https:/www.wunderground.com/ personal-weather-station/dashboard?ID=KVAGROTT2, accessed January 8, 2018).

\section{Site Description}

The two drip sites monitored in this study, named Cable and Prime, are on the western side of Grand Caverns in a chamber called the Drapery Room (Figure 1). Both drips feed actively growing stalagmites and are located within 5 meters of each other. The drips are 0.4 kilometers from the entrance of the cave and approximately 52 meters at depth below the surface of Cave Hill. The Drapery Room is 10 meters above the elevation of the South River which is the approximate elevation of the water table in Cave Hill.

The bedding within the Conococheague is vertical to sub-vertical on the western side of Grand Caverns where the Drapery Room is located and then flattens out to become horizontal to sub-horizontal on the eastern side of the cave. This is because Cave Hill is part of an anticline/syncline pair where the axis of the anticline extends through the larger, eastern portion of the cave (Figure 1). Since discontinuities created by bedding planes act as preferential flow paths for water, the nearly vertical bedding at the drip site can have an important influence on the pathways for vadose water flow that have developed above the Drapery Room.

Although agriculture is prevalent throughout this portion of the Great Valley, the surface of Cave Hill is completely forested. The soil above Grand Caverns is mapped as the Frederick-Christian silt loam and the Christian gravelly fine sandy loam (websoilsurvey.sc.egov.usda. gov, accessed September 20, 2017) that transitions to primarily clay below a depth of $33-36 \mathrm{~cm}$. The total soil depth varies from zero to more than a meter.

\section{Methods \\ Cave Monitoring}

For each site the drip rate was monitored using an Onset ${ }^{\circledR}$ HOBO ${ }^{\circledR}$ tipping bucket rain gauge stationed directly below each drip (Schreiber et al., 2015). The volume of the tipping bucket is $3.73 \mathrm{~mL}$ which partially controlled the resolution at which changes in drip rate were observed. Directly on top of the rain gauge was a Nalgene ${ }^{\circledR}$ reservoir that temporarily stored the drip water until it spilled over into the rain gauge below (Figure 2). On top of the reservoir was a funnel that captured the drip water, and within the funnel was a $\mathrm{HOBO} \AA$ conductivity data logger that measured the electrical conductivity of the water at 15 minute intervals.

Water samples were collected from the Nalgene ${ }^{\circledR}$ reservoir for analysis of major ions and stable isotopes of water. Water sampling frequency ranged from weekly to monthly with higher frequency targeted towards recharge events. All of the samples were filtered on site through a $0.20 \mu \mathrm{m}$ filter to remove any bacteria from the water. Samples for cations and anions were stored in $15 \mathrm{ml}$ polypropylene bottles. Samples for dissolved inorganic carbon (DIC) were stored in clear, $20 \mathrm{ml}$ glass vials with black butyl rubber septa and were filled to a positive meniscus leaving no head space. Samples for stable isotopes of water $\left({ }^{18} \mathrm{O}\right.$ and $\left.{ }^{2} \mathrm{H}\right)$ were stored within clear, $4 \mathrm{ml}$ glass vials with polyseal conical inserts in phenolic caps to prevent evaporation. $\mathrm{CO}_{2}$ concentration in the air was recorded using a Vaisala ${ }^{\circledR}$ handheld $\mathrm{CO}_{2}$ meter, and the temperature and relative humidity was 


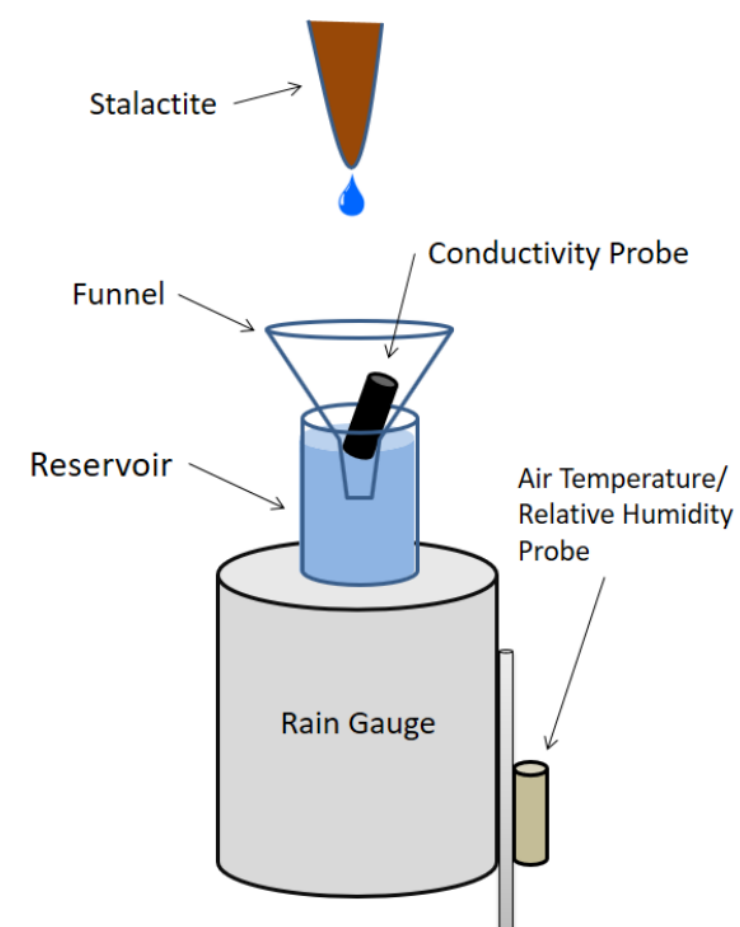

Figure 2. A diagram showing the drip monitoring instrumentation.

continuously measured using a $\mathrm{HOBO} \otimes$ temperature/ relative humidity data logger.

\section{Surface Monitoring}

Three capacitance-based soil moisture probes were installed in November 2015 at the surface of Cave Hill to measure changes in volumetric water content above the cave. The probes were installed at depths ranging from 0.58 meters to 0.98 meters within a sinkhole that was closest to the location of the Drapery Room as if it were projected to the surface (Figure 1). Water content was recorded at 15 minute intervals, and the probes were connected to a $\mathrm{HOBO}{ }^{\circledR}$ Micro Station Data Logger where the data was retrieved on a monthly basis.

Precipitation samples were collected on a bi-weekly to monthly basis for the analysis of stable isotopes of water. Samples were collected from a sealed, plastic rain sampler that was located at the surface of Cave Hill within the sinkhole where soil moisture was being monitored. The volume of water within the bucket was recorded and the samples were stored within $4 \mathrm{ml}$ glass vials with polyseal caps. Once all of the samples were transported back to the laboratory, they were refrigerated until analysis. The meteorological data used in this paper was from a weather station located $1 \mathrm{~km}$ from the cave at the Grottoes fire station.

\section{Results}

The two drip sites showed marked differences in discharge throughout the study period of March 2014 to July 2017. The Cable drip exhibited seasonal changes in flow rate while the Prime drip showed a nearly constant drip rate at $0.018 \mathrm{~L} / \mathrm{h}$ (Figure 3). The Cable drip had a lower flow regime $(0.0037 \mathrm{~L} / \mathrm{h}-0.0075 \mathrm{~L} / \mathrm{h})$ during the summer, spring, and early winter until a precipitation event triggered a sharp increase in drip rate to values as high as $0.328 \mathrm{~L} / \mathrm{h}$. This sudden change in drip rate by at least two orders of magnitude occurred within a 4-7 day period, and corresponded to a sudden increase in electrical conductivity of the water by $80-100 \mu \mathrm{S} /$ $\mathrm{cm}$ (Figure 3). Every year starting in the fall there was a consistent drop in electrical conductivity at the Cable site from values as high as $438 \mu \mathrm{S} / \mathrm{cm}$ to as low as $290 \mu \mathrm{S} /$ $\mathrm{cm}$ during the winter and early spring. Major ion results show that the conductivity is primarily driven by changes in the concentration of calcium plus magnesium cations and corresponding bicarbonate anions (Figure 4).

The soil moisture above the cave ranged from $12 \%-31 \%$ with higher values occurring during the spring at $27 \%-$ $31 \%$ until it began to drop during the summer months and reached low value of $12 \%-15 \%$ in the fall (Figure 5). This dry period persisted until winter, and the soil moisture began to rise back to spring time values. Throughout 2016, there was an apparent soil moisture threshold of approximately $30 \%$ before a drip rate response to precipitation was recorded within the cave (Figure 5).

Despite the observed flow variability between the two sites, the oxygen isotope composition of both drip sites remained nearly equal and constant at $-8.0 \pm 0.1 \%$, with a positive excursion of $\sim 0.5 \%$ over the course of about 4 months after a large storm event in early October 2015 (Figure 2). Unfortunately, precipitation from 2015 was not collected, thus its isotopic composition is unknown; however, the isotopic composition of rainfall typically peaks in the late summer and early fall, thus we surmise that the excursion in drip water composition was caused by the large rainfall events during a time period of low drip rate in the late summer/early fall.

The oxygen isotope composition for precipitation collected above the cave in 2016 had an amount-weighted mean annual value of $-5.8 \pm 0.1 \%$. In comparison, the amount-weighted winter season precipitation (November-April) was $-8.3 \pm 0.1 \%$, a value similar to 


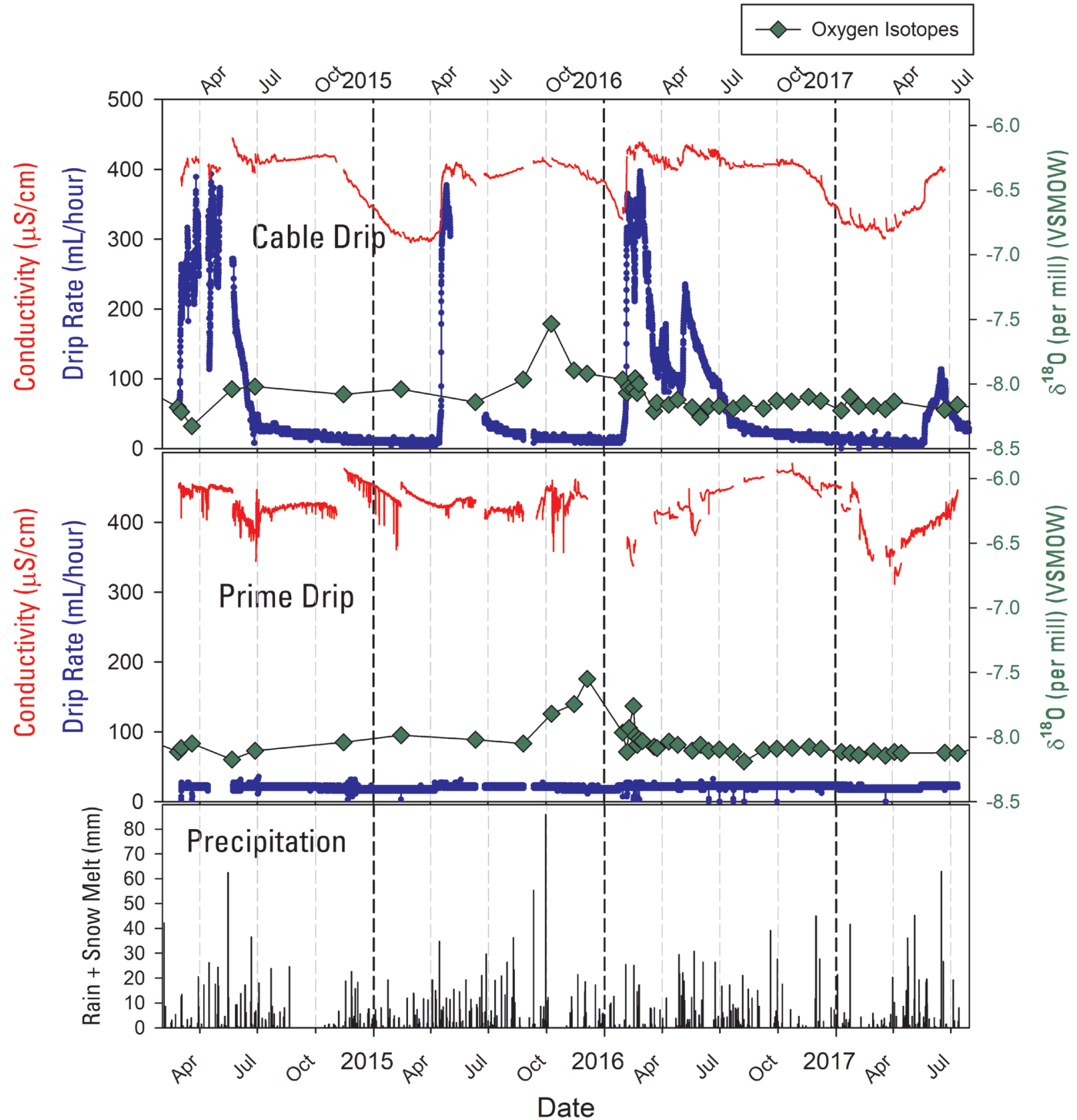

Figure 3. A time series showing the drip rate, electrical conductivity, and the oxygen isotope composition of both drip sites along with precipitation data collected from a nearby weather station in Grottoes, VA (https://www.wunderground.com/personal-weather-station/ dashboard? ID=KVAGROTT2, accessed Jan 08, 2018). Gaps in conductivity and drip rate data are from instrument failure.

the mean oxygen isotope composition of the drip waters (Figure 6).

\section{Discussion}

The annual decrease in discharge at the Cable site corresponds to a drop in soil moisture as observed in
2016 (Figure 5). It is assumed this is a response to an increase in evapotranspiration at the surface during the spring and early summer. Despite there being $524 \mathrm{~mm}$ of precipitation from May 1 to October 31 in 2016, the soil moisture and drip rate continued to drop, and there were no responses in drip rate to precipitation 


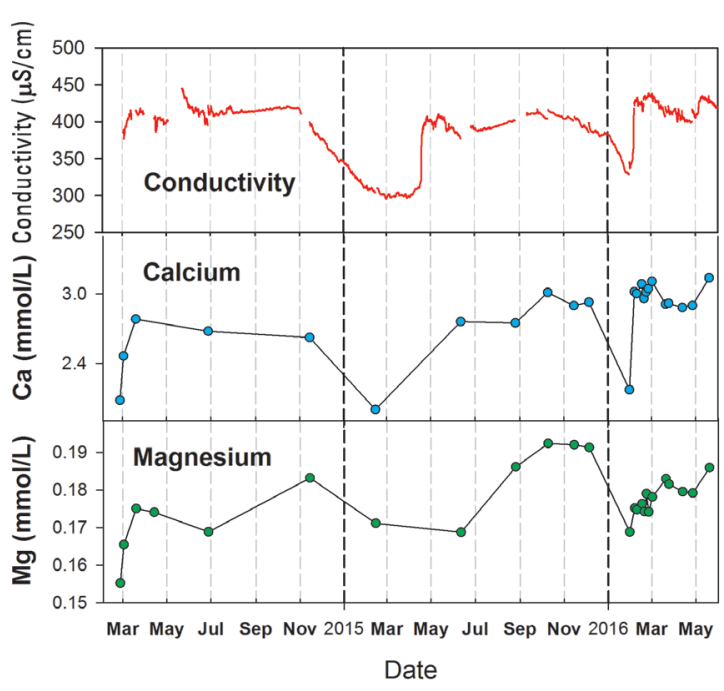

Figure 4. Electrical conductivity of drip water from the Cable site plotted with calcium and magnesium concentrations.

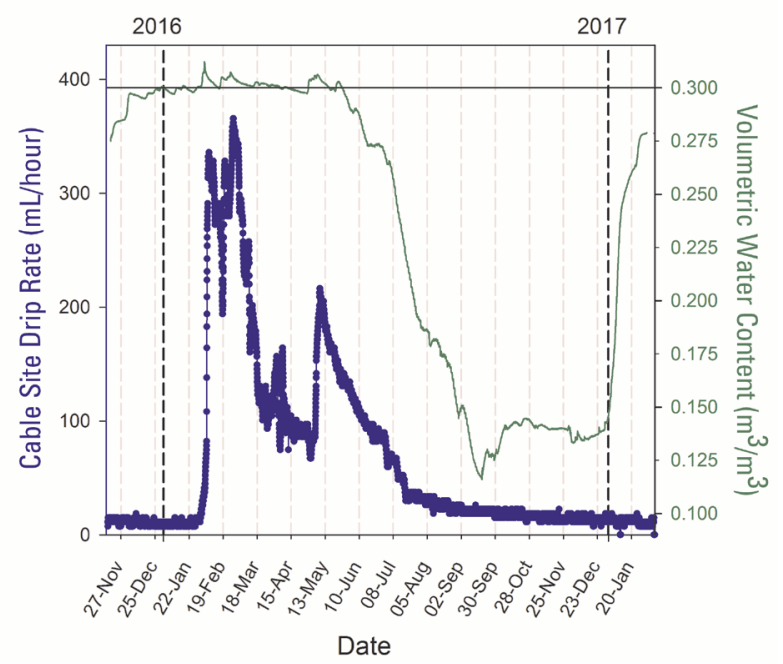

Figure 5. A time series showing the drip rate for the Cable site and the volumetric water content of the soil above Grand Caverns. A $30 \%$ soil moisture threshold is emphasized by the solid, horizontal line.

events throughout this period. The lower flow regime of the Cable site continued throughout the fall and winter; however, the soil moisture began to increase by December as the rate of evapotranspiration dropped and precipitation continued, allowing for the infiltration of water through the soil zone as expressed in the soil moisture record (Figure 5). This increase in soil moisture is interpreted to be the onset of the recharge period above the caverns which continued throughout the winter and early spring. The isotopic composition of the drip waters collected within the cave supports the observed cool season bias towards recharge as the weighted mean oxygen isotope composition of the drip waters is approximately equal to the cool-season weighted mean isotopic composition of precipitation collected above the cave (Figure 6). The relatively constant $\delta^{18} \mathrm{O}$ values observed at both drip sites supports the presence of a perched aquifer within the epikarst that would allow for the mixing and homogenization of vadose water before percolating downward into the cave.

The lower flow regime of the Cable site continued until late winter or early spring when a series of precipitation events triggered the epikarst aquifer to drain into the cave causing a spike in drip rate. After the initial spike in discharge, the Cable drip appears to have a persistent hydraulic connection with the surface, responding to subsequent precipitation events (Figure 3).

The initial waters flushed into the cave at the beginning of each recharge event had greater concentrations of calcium and magnesium which is interpreted to be the result of the waters having reached a higher degree of chemical saturation with carbonate minerals due to storage within the epikarst during the dry season.

The timing and magnitude of the initial annual recharge events varied significantly (Figure 3) with larger

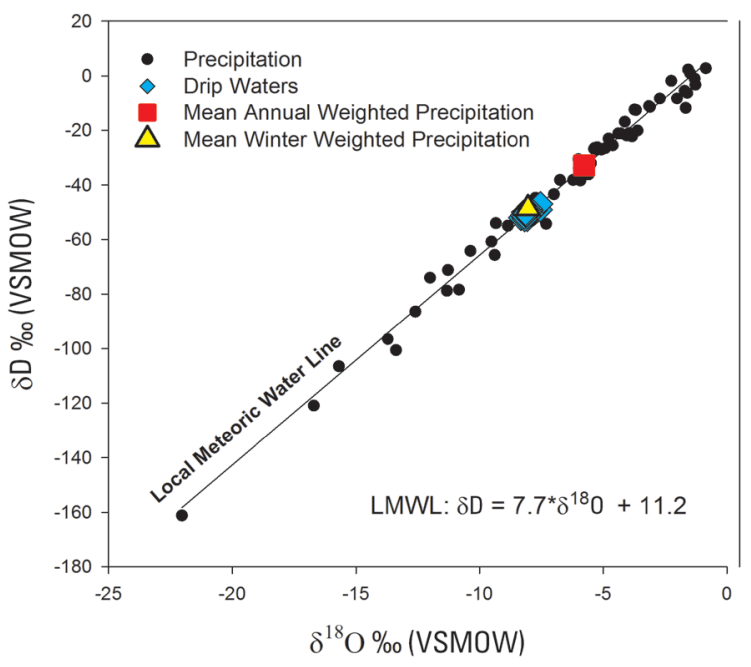

Figure 6. The local meteoric water line plotted with the isotopic composition of the drip waters. Notice the mean winter amountweighted precipitation value is approximately equal to the composition of the drip waters. 
recharge events beginning as early as February (2014, 2016) and smaller events beginning during April or May (2015, 2017). There is no apparent relationship between the amount of precipitation that occurs during the winter season and the magnitude of recharge that occurs during the spring season; however, an apparent volumetric soil moisture threshold of $30 \%$ needs to be overcome in order to initiate a drip response in the cave to precipitation. The temporal extent of the recharge period for the epikarst is also regulated by evapotranspiration rates throughout the fall, winter, and spring which will vary depending upon climatic conditions. Nonetheless, continuous soil moisture measurements are superior to calculated estimates of evapotranspiration for determining periods of excess precipitation necessary to initiate and sustain recharge into the epikarst; however, a multi-year record is needed before modeled predictions can be made between changes in soil moisture, and the timing and magnitude of recharge to the drips.

\section{Summary}

Based upon soil moisture records for 2016 and the isotopic composition of drip waters, results from this study support the hypothesis that the winter season is the crucial recharge period for vadose waters that ultimately take part in recharge to the aquifer. Also, waters sampled during spring recharge events had higher concentrations of dissolved ions compared to waters sampled under lower, winter flow regimes. A longer, multi-year record of soil moisture is needed before definite connections and correlations can be made between rates of precipitation, and the timing and magnitude of recharge events.

\section{Acknowledgements}

The authors thank Lettie Stickley, Nathan Garrison, and the Town of Grottoes for generous access to Grand Caverns during the course of this study. Ben Hardt (formerly with the USGS) implemented the initial setup of the drip monitoring sites. Michael Doughten (USGS) conducted major ion analysis, and Lauren Brandes (USGS) conducted stable isotope analyses of water samples. Any use of trade, firm, or product names is for descriptive purposes only and does not imply endorsement by the U.S. Government.

\section{References}

Doctor DH, Alexander CE, Jameson RA, Alexander SC. 2015. Hydrologic and geochemical dynamics of vadose zone recharge in a mantled karst aquifer:
Results of monitoring drip waters in Mystery Cave, Minnesota. National Cave and Karst Research Institute Symposium 5, Proceedings of the 14th Multidisciplinary Conference on Sinkholes and the Engineering and Environmental Impacts of Karst; 2015 October 5-9; Rochester, Mn. National Cave and Karst Research Institute. p.19-30.

Doctor DH, Orndorff W, Maynard J, Heller MJ, Casile GC. 2014. Karst geomorphology and hydrology of the Shenandoah Valley near Harrisonburg, Virginia. In Bailey CM, Coiner LV, eds., Elevating Geoscience in the Southeastern United States: New Ideas about Old Terranes_-Field Guides for the GSA Southeastern Section Meeting, Blacksburg, Virginia, 2014: Geological Society of America Field Guide 35, p. 161-213.

Eagle SR, Orndorff W, Schwartz B, Doctor DH, Gerst J, Schreiber M. 2016. Analysis of hydrologic and geochemical time-series data at James Cave, Virginia: Implications for epikarst influence on recharge in Appalachian karst aquifers. Caves and Karst Across Time. In Feinberg JM, Gao Y, Alexander CE, eds., GSA Special Papers Vol. 516. Chapter 13.

Gathright, TM II, Henika WS, Sullivan JL III. 1978. Geology of the Grottoes Quadrangle, Virginia. Virginia Division of Mineral Resources. Publication 10.

Lachniet MS. 2009. Climatic and environmental controls on speleothem oxygen-isotope values. Quaternary Science Reviews 28: 412-432.

Mathias SA, Sorenson JPR, Butler AP. 2017. Soil moisture data as a constraint for groundwater recharge estimation. Journal of Hydrology 552: 258-266.

Schreiber ME, Schwartz BF, Orndorff W, Doctor DH. 2015. Instrumenting Caves to Collect Hydrologic and Geochemical Data: Case Study from James Cave, Virginia. Younos T, Parece TE, eds., Advances in Watershed Science and Assessment, The Handbook of Environmental Chemistry 33.

Soil Survey Geographic (SSURGO) database for Augusta County, Virginia. United States Department of Agriculture, Soil Conservation Service. https://websoilsurvey.sc.egov.usda.gov/.

Williams PW. 2008. The role of the epikarst in karst and cave hydrogeology: a review. International Journal of Speleology 37: 1-10. 
